\title{
PENGARUH DISIPLIN DAN KOMPENSASI TERHADAP KINERJA PEGAWAI INDONET
}

\author{
Oleh: \\ Zuhaidi $^{1}$ \\ Herny Pujiati ${ }^{2}$ \\ Mahasiswa Fakultas Ekonomi Universitas MH. Thamrin ${ }^{1}$ \\ Dosen Fakultas Ekonomi Universitas MH. Thamrin ${ }^{2}$ \\ Email: \\ herniaries@gmail.com²
}

\begin{abstract}
ABSTRAK
Kinerja Perusahaan yang berkualitas sangat ditentukan oleh kinerja pegawai. Kinerja pegawai menjadi perhatian utama, baik bagi rekanan maupun publik dalam menilai hasil pegawai yang dilakukan. Tujuan dari penelitian ini adalah untuk mengetahui pengaruh disiplin dan kompensasi terhadap kinerja pegawai pada PT. Indo Internet. Populasi pada penelitian ini adalah pegawai yang bekerja di PT. Indo internet. Penelitian ini dilaksanakan dari April sampai Juli 2017. Teknik pengambilan data pada penelitian ini adalah menggunakan metode slovin dengan jumlah responden sebanyak 45 responden. Data yang digunakan dalam penelitian ini dikategorikan sebagai data primer. Teknik pengumpulan data yang digunakan melalui penyebaran kuisioner. Pengujian data dilakukan dengan uji reliabilitas, validitas, asumsi klasik kemudian data diolah dan dianalisis dengan menggunakan uji korelasi dan regresi linier berganda dengan menggunakan SPSS 23.0. Berdasarkan hasil penelitian ini, menunjukkan bahwa terdapat pengaruh dan signifikan dari disiplin terhadap kinerja pegawai pada PT. Indo Internet dengan nilai sig $0.000<0.005$. Pada Kompensasi terdapat pengaruh dan signifikan terhadap pegawai dengan nilai sig $0.001<0.05$. Pengaruh disiplin dan kompensasi terhadap kinerja pegawai sebesar $67.50 \%$. Sisanya yaitu sebesar $32.50 \%$ dipengaruhi oleh faktor lain. Hasil penelitian ini menunjukkan bahwa disiplin dan kompensasi berpengaruh secara signifikan terhadap kinerja pegawai baik secara parsial maupun secara simultan
\end{abstract}

Kata Kunci: disiplin, kompensasi, kinerja pegawai 


\section{A. PENDAHULUAN}

Sumber daya manusia mempunyai peranan penting baik secara perorangan ataupun kelompok, dan sumber daya manusia merupakan salah satu penggerak utama atas kelancaran jalannya kegiatan sebuah organisasi, bahkan maju atau mundurnya perusahaan ditentukan oleh keberadaan sumber daya manusianya. Untuk itu setiap perusahaan perlu memperhatikan dan mengatur keberadaan pegawainya sebagai usaha meningkatkan kinerja yang baik. Keberhasilan suatu organisasi sangat dipengaruhi oleh kinerja individu pegawainya. Setiap organisasi maupun perusahaan akan selalu berusaha untuk meningkatkan kinerja pegawai, dengan harapan apa yang menjadi tujuan perusahaan akan tercapai. Salah satu cara yang ditempuh oleh perusahaan dalam meningkatkan kinerja pegawainya, misalnya dengan menerapkan kedisiplinan, pendidikan, pelatihan, pemberian kompensasi yang layak, pemberian motivasi, dan menciptakan lingkungan kerja yang kondusif. Sukses tidaknya seorang pegawai dalam bekerja akan dapat diketahui apabila perusahaan atau organisasi yang bersangkutan menerapkan sistem penilaian kinerja. Kinerja adalah hasil kerja yang dapat dicapai oleh seseorang atau sekelompok orang dalam suatu organisasi, sesuai dengan wewenang dan tanggung jawab masing-masing dalam rangka upaya mencapai tujuan organisasi yang bersangkutan secara legal, tidak melanggar hukum dan sesuai dengan moral maupun etika.

Salah satu hal yang mempengaruhi kinerja pegawai adalah disiplin. Disiplin sendiri merupakan satu dari beberapa faktor yang mempengaruhi kinerja pegawai. Karena tanpa adanya disiplin, maka segala kegiatan yang akan dilakukan akan mendatangkan hasil yang kurang memuaskan dan tidak sesuai dengan harapan. Hal ini dapat mengakibatkan kurangnya pencapaian sasaran dan tujuan organisasi atau perusahaan serta dapat juga menghambat jalannya program organisasi yang dibuat. Dibutuhkan peningkatan kinerja pegawai agar dapat melaksanakan tugas yang ada sebaik mungkin. Karena itu faktor disiplin mempunyai pengaruh serta peran yang penting terhadap peningkatan kinerja pegawai. Jika dilihat secara langsung, faktor kedisiplinan memegang peranan yang amat penting dalam pelaksanaan tugas sehari-hari para pegawai. Seorang pegawai yang mempunyai tingkat kedisiplinan yang tinggi akan tetap bekerja dengan baik walaupun tanpa diawasi oleh atasan. Seorang pegawai yang disiplin tidak akan mencuri waktu kerja untuk melakukan hal-hal lain yang tidak ada kaitannya dengan pekerjaan. Demikian juga pegawai yang mempunyai kedisiplinan akan mentaati peraturan yang ada dalam lingkungan kerja dengan kesadaran yang tinggi tanpa ada rasa paksaan.

Pada akhirnya pegawai yang mempunyai kedisiplinan yang tinggi akan mempunyai kinerja yang baik bila dibanding dengan para pegawai yang bermalasmalasan karena pegawai yang disiplin akan menggunakan waktu kerjanya sebaik mungkin untuk melaksanakan pekerjaan sesuai dengan target yang telah ditetapkan.

Selain disiplin faktor kompensasi juga tidak kalah penting dalam meningkatkan kinerja pegawai. Kompensasi dapat menjadi pendorong seseorang melaksanakan suatu kegiatan guna mendapatkan hasil yang terbaik. Oleh karena itulah tidak heran jika pegawai yang mempunyai kompensasi yang tinggi biasanya 
mempunyai kinerja yang baik. Untuk itu selain disiplin alangkah lebih baik jika kompensasi pegawai perlu juga ditingkatkan agar pegawai dapat menghasilkan kinerja yang terbaik. Berdasarkan uraian di atas, terlihat betapa pentingnya peranan faktor disiplin dan kompensasi dalam meningkatkan kinerja pegawai.

Pegawai yang kurang disiplin dan kompensasi akan sulit meningkatkan produktivitas dan tidak akan mungkin bisa merealisasikan pencapaian tujuan yang ditetapkan perusahaan. Begitupun yang terjadi pada pegawai PT. INDO INTERNET (INDONET) kurangnya penegakan kedisiplinan dan kompensasi yang diterima oleh pegawai sehingga pencapaian kinerja yang diharapkan perusahaan belum maksimal. Oleh sebab itu seorang pemimpin yang baik harus berusaha agar para bawahannya mempunyai disiplin dan kompensasi yang baik.

Kompensasi merupakan suatu kekuatan potensial yang dapat memicu semangat dari seorang manusia, yang dapat diperoleh dari perusahaan baik yang secara finansial atau non finansial sendiri atau yang intinya berkisar sekitar materil dan non materil, yang dapat mempengaruhi hasil kinerjanya secara positif, tergantung pada situasi dan kondisi yang dihadapi orang yang bersangkutan. Memberikan kompensasi seorang pegawai untuk bekerja biasanya merupakan hal yang rumit, karena kompensasi itu melibatkan faktor-faktor individual dan faktorfaktor organisasional. Kompensasi dari para pegawai akan saling berbeda, sesuai dengan tingkat pendidikan dan kondisi perusahaan. Orang yang berpendidikan biasanya menempati jabatan yang tinggi dan biasanya menginginkan kompensasi yang setimpal dan semakin lama seseorang berkerja semakin banyak juga pengalaman kerjanya biasanya mereka memiliki tuntutan untuk naik bayarannya. Maka sistem kompensasi pun berbeda, tidak semata-mata ditentukan oleh tingkat pendidikan dan kondisi perusahaan saja melainkan juga dipengaruhi oleh faktorfaktor kebutuhan lainnya.

\section{B. TINJAUAN PUSTAKA}

\section{Pengertian Sumber Daya Manusia}

Hasibuan (2012) Manajemen Sumber Daya Manusia dapat diartikan sebagai ilmu dan seni yang mengatur dan peranan tenaga kerja agar efektif dan efisien dalam penggunaan kemampuan manusia agar dapat mencapai tujuan di setiap perusahaan.

Flippo dalam Hasibuan (2009)" sebagai berikut : Manajemen Sumber Daya Manusia adalah perencanaan, pengorganisasian, pengarahan, dan pengawasan kegiatan-kegiatan pengadaan, pengembangan, pemberian kompensasi, pengintegrasian, pemeliharaan dan pelepasan sumber daya manusia agar tercapai berbagai tujuan individu, organisasi, dan masyarakat.

\section{Tujuan Manajemen Sumber Daya Manusia}

Menurut Cushway dalam Sutrisno (2009) "Tujuan manajemen sumber daya manusia meliputi :

1. Memberi pertimbangan kepada manajemen dalam membuat kebijakan sumber daya manusia untuk memastikan bahwa organisasi memiliki pekerja yang bermotivasi dan memiliki kinerja yang tinggi, memiliki pekerja yang selalu siap mengatasi perubahan dan memenuhi kewajiban pekerjaan secara legal. 
2. Mengimplementasikan dan mejaga semua kebijakan dan prosedur sumber daya manusia yang memungkinkan organisasi mampu mencapai tujuannya.

3. Membantu dalam pengembangan arah keseluruhan organisasi dan strategi, khususnya yang berkaitan dengan implikasi sumber daya manusia.

4. Memberi dukungan dan kondisi yang akan membantu manajer lini mencapai tujuannya.

5. Menangani krisis dan berbagai situasi sulit dalam hubungan antar pekerja untuk meyakinkan bahwa mereka tidak menghambat organisasi dalam mencapai tujuannya.

6. Menyediakan media komunikasi antara pekerja dan manajemen organisasi.

7. Bertindak sebagai pemelihara standar organisasional dan nilai dalam manajemen sumber daya manusia.

\section{Definisi Disiplin}

Menurut Singodimedjo yang dikutip Sutrisno (2009) mengatakan disiplin adalah Sikap kesediaan dan kerelaan seseorang untuk mematuhi dan menaati norma-norma peraturan yang berlaku di sekitarnya.

Disiplin yang baik akan mempercepat tujuan perusahaan, sedangkan disiplin yang merosot akan menjadi penghalang dan memperlambat pencapaian tujuan perusahaan. Bentuk disiplin yang baik akan tercermin pada suasana, yaitu :

1. Tingginya rasa kepedulian karyawan terhadap pencapaian tujuan perusahaan.

2. Tingginya semangat dan gairah kerja dan inisiatif para karyawan dalam melakukan pekerjaan.

3. Besarnya rasa tanggung jawab para karyawan untuk melaksanakan tugas dengan sebaik-baiknya.

4. Berkembangnya rasa memiliki dan rasa solidaritas yang tinggi dikalangan karyawan.

5. Meningkatkan efisiensi dan produktivitas kerja para karyawan.

Disiplin merupakan perasaan taat dan patuh terhadap nilai-nilai yang dipercaya termasuk melakukan pekerjaan tertentu yang menjadi tanggung jawabnya. Pendisiplinan adalah usaha-usaha untuk menanamkan nilai ataupun pemaksaan agar subjek memiliki kemampuan untuk menaati sebuah peraturan.

\section{Faktor-Faktor Yang Memengaruhi Disiplin}

Menurut Singodimedjo yang dikutip oleh Sutrisno (2009) faktor yang mempengaruhi disiplin adalah :

1. Besar kecilnya pemberian kompensasi

Besar kecilnya kompensasi dapat mempengaruhi tegaknya disiplin. Para karyawan akan mematuhi segala peraturan yang berlaku, bila ia merasa mendapat jaminan balas jasa yang setimpal dengan jerih payahnya yang telah dikontribusikan bagi perusahaan. Bila ia menerima kompensasi yang memadai, mereka akan dapat bekerja tenang dan tekun, serta selalu berusaha bekerja dengan sebaik-baiknya. Akan tetapi, bila ia merasa kompensasi yang diterimanya jauh dari memadai, maka ia akan berpikir mendua, dan berusaha untuk mencari 
tambahan penghasilan lain di luar, sehingga menyebabkan ia sering mangkir, sering minta izin keluar.

2. Ada tidaknya keteladanan pimpinan dalam perusahaan

Keteladanan pimpinan sangat penting sekali, karena dalam lingkungan organisasi, semua karyawan akan selalu memerhatikan bagaimana pimpinan dapat menegakkan disiplin dirinya dan bagaimana ia dapat mengendalikan dirinya dari ucapan, perbuatan, dan sikap yang dapat merugikan aturan disiplin yang sudah ditetapkan.

3. Ada tidaknya aturan pasti yang dapat dijadikan pegangan

Pembinaan disiplin tidak akan dapat terlaksana dalam organisasi, bila tidak ada aturan tertulis yang pasti untuk dapat dijadikan pegangangan bersama. Disiplin tidak mungkin ditegakkan bila peraturan yang dibuat hanya berdasarkan instruksi lisan yang dapat berubah-ubah sesuai dengan kondisi dan situasi.

4. Keberanian pimpinan dalam mengambil tindakan

Bila seorang karyawan yang melanggar disiplin, maka perlu ada keberanian pimpinan untuk mengambil tindakan yang sesuai dengan tingkat pelanggaran yang dibuatnya. Dengan adanya tindakan terhadap pelanggaran disiplin, sesuai dengan sanksi yang ada, maka semua karyawan akan merasa terlindungi, dan dalam hatinya berjanji tidak akan berbuat hal yang serupa.

5. Ada tidaknya pengawasan pimpinan

Dalam setiap kegiatan yang dilakukan oleh perusahaan perlu ada pengawasan, yang akan mengarahkan para karyawan agar dapat melaksanakan pekerjaan dengan tepat dan sesuai dengan yang telah ditetapkan.

6. Ada tidaknya perhatian kepada para karyawan

Karyawan adalah manusia yang mempunyai perbedaan karakter antara yang satu dengan yang lain. Seorang karyawan tidak hanya puas dengan penerimaan kompensasi yang tinggi, pekerjaan yang menantang, tetapi juga mereka masih membutuhkan perhatian yang besar dari pimpinannya sendiri.

Keluhan dan kesulitan mereka ingin didengar, dicarikan jalan keluarnya dan sebagainya. Pimpinan yang berhasil memberi perhatian yang besar kepada para karyawan akan dapat menciptakan disiplin kerja yang baik.

7. Diciptakan kebiasaan-kebiasaan yang mendukung tegaknya disiplin antara lain :

a. Saling menghormati, bila ketemu di lingkungan pekerjaan

b. Melontarkan pujian sesuai dengan tempat dan waktunya, sehingga para karyawan akan turut merasa bangga dengan pujian tersebut

c. Sering mengikutsertakan karyawan dalam pertemuan-pertemuan, apalagi pertemuan yang berkaitan dengan nasib dan pekerjaan mereka

d. Memberitahu bila ingin meninggalkan tempat kepada rekan sekerja, dengan menginformasikan, ke mana dan untuk urusan apa, walaupun kepada bawahan sekalipun

\section{Kompensasi}

Kompensasi adalah semua pendapatan yang berbentuk uang, barang langsung atau tidak langsung yang diterima karyawan sebagai imbalan atas jasa yang diberikan kepada perusahaan (Malayu S.P. Hasibuan, 2009,118). 
Kompensasi merupakan sesuatu yang diterima karyawan sebagai pengganti kontribusi jasa mereka pada perusahaan (Rivai, 2007)

Menurut Notoatmodjo dalam Sutrisno (2009) ada beberapa tujuan dari kompensasi yang perlu diperhatikan, yaitu: Menghargai prestasi kerja; Menjamin keadilan; Mempertahankan karyawan; Memperoleh karyawan yang bermutu; Pengendalian biaya; Memenuhi peraturan-peraturan.

Tohardi dalam Sutrisno (2009) mengemukakan ada beberapa faktor yang memengaruhi pemberian kompensasi, yaitu : Produktivitas; Kemampuan untuk membayar; Kesediaan untuk membayar; Penawaran dan permintaan tenaga kerja.

\section{Kinerja}

Mangkunegara (2013) mendefinisikan kinerja sebagai istilah kinerja berasal dari kata job performance atau actual performance (prestasi kerja atau prestasi sesungguhnya yang dicapai seseorang) yaitu hasil kerja secara kualitas dan kuantitas yang dicapai oleh seorang pegawai dalam melaksanakan tugasnya sesuai dengan tanggung jawab yang diberikan kepadanya. Menurut Wibowo (2007) pengertian kinerja adalah : "Tentang melakukan pekerjaan dan hasil yang dicapai dari pekerjaan tersebut, tentang apa yang dikerjakan dan bagaimana mengerjakannya."

Mangkunegara (2013) menjelaskan faktor yang mempengaruhi kinerja adalah faktor kemampuan dan faktor motivasi.

1. Faktor kemampuan

Secara psikologis, kemampuan pegawai terdiri dari kemampuan potensi (IQ) dan kemampuan reality (knowledge + skill). Artinya, pegawai yang memiliki IQ di atas rata-rata (IQ 110 - 120).

Dengan pendidikan yang memadai untuk jabatannya dan terampil dalam mengerjakan pekerjaan sehari-hari, maka ia akan lebih mudah mencapai kinerja yang diharapkan. Oleh karena itu, pegawai perlu ditempatkan pada pekerjaan yang sesuai dengan keahliannya.

2. Faktor motivasi

Motivasi terbentuk dari sikap seseorang pegawai dalam menghadapi situasi kerja. Motivasi merupakan kondisi yang menggerakan diri pegawai yang terarah untuk mencapai tujuan organisasi. Sikap mental merupakan kondisi mental yang mendorong diri pegawai untuk berusaha mencapai prestasi kerja secara maksimal. Sikap mental seorang pegawai harus sikap mental yang siap secara psikofisik (siap secara mental, fisik, tujuan, dan situasi). Artinya, seorang pegawai harus siap mental, maupun fisik, memahami tujuanutama dan target kerja yang akan dicapai, mampu memanfaatkan, dan menciptakan situasi kerja.

Menurut Handoko $(2011,135)$, tujuan penilaian kinerja dapat dirincikan sebagai berikut :

Perbaikan kinerja;

Umpan balik pelaksanaan kerja memungkinkan karyawan, manajer dan departemen personalia dapat membetulkan kegiatan-kegiatan mereka untuk memperbaiki kinerja. 
1. Penyesuaian-penyesuaian kompensasi; Evaluasi kinerja membantu para pengambil keputusan dalam menentukan kenaikan gaji, pemberian bonus dan bentuk kompensasi lainnya.

2. Keputusan-keputusan penempatan; Promosi, transfer dan demosi biasanya didasarkan pada prestasi kerja masa lalu atau antisipasinya. Promosi sering merupakan bentuk penghargaan terhadap kinerja masa lalu.

3. Kebutuhan-kebutuhan latihan dan pengembangan; Kinerja yang buruk mungkin menunjukan kebutuhan latihan. Demikian juga kinerja yang baik mungkin mencerminkan potensi yang harus dikembangkan.

4. Perencanaan dan pengembangan karier; Umpan balik kinerja mengarahkan keputusan-keputusan karier, yaitu tentang jalur karier tertentu yang harus diteliti.

5. Penyimpangan-penyimpangan proses staffing; Kinerja yang baik atau jelek mencerminkan kekuatan atau kelemahan prosedur staffing departemen Sumber Daya Manusia.

6. Ketidak-akuratan informasi; Kinerja yang jelek mungkin menunjukkan kesalahan-kesalahan dalam informasi analisis jabatan, rencana-rencana sumber daya manusia, atau komponen-komponen lain sistem informasi manajemen personalia. Menggantungkan diri pada informasi yang tidak akurat dapat menyebabkan keputusan-keputusan yang diambil tidak tepat.

7. Kesalahan-kesalahan desain pekerjaan

Kinerja yang jelek mungkin merupakan suatu tanda kesalahan dalam desain pekerjaan. Penilaian kinerja membantu diagnosa kesalahan-kesalahan tersebut.

Standar kinerja

Menurut Wirawan $(2009,67)$ "Standar kinerja adalah target, sasaran, tujuan upaya kerja karyawan dalam kurun waktu tertentu. Dalam melaksanakan pekerjaannya, karyawan harus mengarahkan semua tenaga, pikiran, ketrampilan, pengetahuan, dan waktu kerjanya untuk mencapai apa yang ditentukan oleh standar kinerja".

\section{METODE PENELITIAN}

\section{Analisis Data dan Pembahasan}

Penyajian data

Hasil kuisioner yang disebar Pengolahan data dalam penulisan skripsi ini menggunakan program Microsoft Excel dan Statistical Package For the Social Science (SPSS) versi 23.0. Data yang diolah adalah pemahaman responden mengenai pengaruh disiplin dan kompensasi terhadap kinerja pegawai.

Identifikasi responden

1. Profil responden berdasarkan jenis kelamin

Berdasarkan jenis kelamin peneliti membagi menjadi dua kategori, yaitu laki-laki dan perempuan. Pada tabel IV.1 dapat dilihat persentase responden laki-laki dan perempuan sebagai berikut : 
Tabel 1

Jenis Kelamin

\begin{tabular}{llrrrr}
\hline & & & & \multicolumn{2}{c}{ Cumulative } \\
& & Frequency & Percent & Valid Percent & \multicolumn{2}{c}{ Percent } \\
\hline Valid & Laki laki & 35 & 77,8 & 77,8 & 77,8 \\
& Perempuan & 10 & 22,2 & 22,2 & 100,0 \\
& Total & 45 & 100,0 & 100,0 & \\
\hline
\end{tabular}

Sumber: Output SPSS

Berdasarkan tabel 1, dapat diketahui bahwa 35 responden atau $77.8 \%$ jumlahnya adalah laki-laki, dan sisanya 10 responden atau $22.2 \%$ jumlahnya adalah perempuan. Secara keseluruhan umumnya pegawai yang menjadi responden dalam kuisioner adalah berjenis kelamin laki-laki yang memilki presentase $77.8 \%$

2 Profil responden berdasarkan usia

Berdasarkan usia, peneliti membagi menjadi 2 kategori, yaitu : $1=19$ sampai 22 tahun dan $2=23$ sampai 26 tahun. Hal ini dapat dilihat dengan persentase usia sebagai berikut :

Tabel 2

Usia

\begin{tabular}{cccccc}
\hline & Frequency & Percent & Valid Percent & $\begin{array}{c}\text { Cumulative } \\
\text { Percent }\end{array}$ \\
\hline \multirow{3}{*}{ Valid } & 19-22thn & 22 & 48,9 & 48,9 & 48,9 \\
& 23-26thn & 23 & 51,1 & 51,1 & 100,0 \\
& Total & 45 & 100,0 & 100,0 & \\
\hline \multicolumn{5}{c}{ Sumber: Output SPSS }
\end{tabular}

Berdasarkan tabel 2, dapat diketahui bahwa 22 responden atau 48.9\% berusia antara 19 sampai 22 tahun dan 23 responden atau $51.1 \%$ berusia antara 23 sampai 26 tahun. Secara keseluruhan umumnya pegawai yang menjadi responden dalam kuisioner ini berusia 23 sampai 26 tahun.

3. Profil responden berdasarkan pendidikan

Peneliti membagi kategori responden dalam lima bagian akademik yang dimiliki oleh responden yaitu : D3, S1, SMA, SMK dan STM. Dari kuesioner yang disebar peneliti, dapat diketahui hasilnya sebagai berikut :

Tabel IV.3

Pendidikan

\begin{tabular}{cccccc}
\hline & & Frequency & Percent & Valid Percent & $\begin{array}{c}\text { Cumulative } \\
\text { Percent }\end{array}$ \\
\hline \multirow{4}{*}{ Valid } & D3 & 4 & 8,9 & 8,9 & 8,9 \\
& S1 & 5 & 11,1 & 11,1 & 20,0 \\
& SMA & 8 & 17,8 & 17,8 & 37,8 \\
& SMK & 22 & 48,9 & 48,9 & 86,7 \\
& STM & 6 & 13,3 & 13,3 & 100,0 \\
& Total & 45 & 100,0 & 100,0 & \\
\hline \multicolumn{4}{c}{} \\
\end{tabular}

Berdasarkan tabel.3, terlihat bahwa 4 responden atau $8.9 \%$ memiliki pendidikan D3. 5 responden atau $11.1 \%$ memiliki pendidikan S1, 8 responden atau $17.8 \%$ memiliki pendidikan SMA, 22 responden atau $48.9 \%$ memiliki pendidikan SMK dan 6 responden atau 13,3\% memiliki 
pendidikan STM. Secara keseluruhan umumnya pegawai yang menjadi responden dalam kuisioner ini memiliki pendidikan SMK.

4. Profil responden berdasarkan lama kerja

Berdasarkan masa kerja yang dimiliki karyawan, peneliti membagi menjadi 2 kategori yaitu : $1=1$ sampai 2 tahun dan $2=3$ sampai 4 tahun. Hal ini dapat dilihat dari persentase masa kerja pegawai sehingga akan dapat rata-rata keseluruhan masa kerja pegawai yang dapat dilihat dari tabel IV.4 sebagai berikut :

Tabel 4

Lama Kerja

\begin{tabular}{|c|c|c|c|c|c|}
\hline \multicolumn{2}{|c|}{} & Frequency & Percent & Valid Percent & $\begin{array}{c}\text { Cumulative } \\
\text { Percent }\end{array}$ \\
\hline \multirow{3}{*}{ Valid } & 1-2thn & 36 & 80,0 & 80,0 & 80,0 \\
\cline { 2 - 6 } & $3-4$ thn & 9 & 20,0 & 20,0 & 100,0 \\
\cline { 2 - 6 } & Total & 45 & 100,0 & 100,0 & \\
\hline \multicolumn{5}{|c}{ Sumber: Output SPSS }
\end{tabular}

Berdasarkan tabel 4, terlihat bahwa 36 responden atau $80.0 \%$ memiliki masa kerja 1 sampai 2 tahun dan 9 responden atau $20.0 \%$ memiliki masa kerja 3 sampai 4 tahun. Secara keseluruhan umumnya pegawai yang menjadi responden dalam kuisioner ini memiliki masa kerja 1 sampai 2 tahun.

\section{HASIL DAN PEMBAHASAN}

Rekapitulasi jawaban responden

Berdasarkan hasil jawaban kuisioner yang telah disebarkan kepada responden, maka dapat diketahui respon pegawai dalam pengaruh disiplin dan kompensasi terhadap kinerja pegawai yang dilakukan, yaitu meliputi :

1) Tanggapan pegawai mengenai disiplin

2) Tanggapan pegawai mengenai kompensasi

3) Tanggapan pegawai mengenai kinerja pegawai

Semua tanggapan tersebut disusun dalam bentuk kuisioner dengan 5 pilihan jawaban yaitu Sangat Setuju (SS), Setuju (S), Kurang Setuju (KS), Tidak Setuju (TS), Sangat Tidak Setuju (STS).

Tabel 5

Rekapitulasi Jawaban Responden Variabel Disiplin

\begin{tabular}{|c|c|c|c|c|c|c|c|c|}
\hline \multirow{2}{*}{ No } & \multirow{2}{*}{ Pertanyaan (Disiplin) } & & \multicolumn{5}{|c|}{ Skor Jawaban Responden } & \multirow{2}{*}{$\begin{array}{l}\text { Jumlah } \\
\text { Skor }\end{array}$} \\
\hline & & & 5 & 4 & 3 & 2 & $\mathbf{1}$ & \\
\hline \multirow[t]{2}{*}{1} & $\begin{array}{l}\text { Tepat waktu datang } \\
\text { kekantor }\end{array}$ & $\mathrm{f}$ & 14 & 22 & 3 & 6 & 0 & 179 \\
\hline & & $\%$ & 31,1 & 48,9 & 6,7 & 13,3 & 0 & 79,55 \\
\hline 2 & $\begin{array}{c}\text { Tepat waktu } \\
\text { menvelesaikan tugas }\end{array}$ & $\mathrm{f}$ & 2 & 27 & 12 & 4 & 0 & 162 \\
\hline & & $\%$ & 4,4 & 60,0 & 26,7 & 8,9 & 0 & 72 \\
\hline 3 & Mematuhi standar kerja & $\begin{array}{l}\mathrm{f} \\
\%\end{array}$ & $\begin{array}{c}7 \\
15,6\end{array}$ & $\begin{array}{c}18 \\
40,0\end{array}$ & $\begin{array}{c}8 \\
17,8\end{array}$ & $\begin{array}{c}9 \\
20,0\end{array}$ & $\begin{array}{c}3 \\
6,7\end{array}$ & $\begin{array}{c}152 \\
67,55\end{array}$ \\
\hline 4 & $\begin{array}{l}\text { Memiliki tanggung } \\
\text { jawab terhadap tugas }\end{array}$ & $\mathrm{f}$ & 10 & 19 & 7 & 7 & 2 & 163 \\
\hline
\end{tabular}




\begin{tabular}{|c|c|c|c|c|c|c|c|c|}
\hline & & $\%$ & 22,2 & 42,2 & 15,6 & 15,6 & 4,4 & 72,44 \\
\hline \multirow[t]{2}{*}{5} & $\begin{array}{c}\text { Mengerjakan tugas } \\
\text { sesuai bidangnya } \\
\text { (Divisi masing-masing) }\end{array}$ & $\mathrm{f}$ & 9 & 18 & 13 & 5 & 0 & 166 \\
\hline & Berani menerima sanksi & $\%$ & 20,0 & 40,0 & 28,9 & 11,1 & 0 & 73,77 \\
\hline \multirow[t]{2}{*}{6} & $\begin{array}{l}\text { bila melakukan } \\
\text { kesalahan }\end{array}$ & $\mathrm{f}$ & 15 & 14 & 6 & 6 & 4 & 165 \\
\hline & & $\%$ & 33,3 & 31,1 & 13.3 & 13,3 & 8,9 & 73,33 \\
\hline \multirow[t]{2}{*}{7} & Taat terhadap pimpinan & $\mathrm{f}$ & 13 & 17 & 12 & 3 & 0 & 175 \\
\hline & & $\%$ & 28,9 & 37,8 & 26,7 & 6,7 & 0 & 77,77 \\
\hline \multirow[t]{4}{*}{8} & $\begin{array}{c}\text { Mengikuti cara kerja } \\
\text { yang ditentukan oleh } \\
\text { perusahaan }\end{array}$ & $\mathrm{f}$ & 11 & 23 & 9 & 0 & 2 & 176 \\
\hline & & $\%$ & 24,4 & 51,1 & 20,0 & 0 & 4,4 & 78,22 \\
\hline & Tatol & $\mathrm{f}$ & 81 & 158 & 70 & 40 & 11 & 1338 \\
\hline & lotal & $\%$ & 22,5 & 43,88 & 19,44 & 11,11 & 3,05 & 74,32 \\
\hline
\end{tabular}

Pada Tabel 5 dapat dilihat bahwa total frekuensi jawaban dan persentase jumlah skor responden tentang variabel disiplin yang menyatakan sangat setuju terdapat 81 jawaban $(22,5 \%)$, setuju 158 jawaban $(43,88 \%)$, kurang setuju 70 jawaban $(19,44 \%)$, tidak setuju 40 jawaban $(11,11 \%)$ dan sangat tidak setuju 11 jawaban $(3,05 \%)$.

Kemudian secara keseluruhan persentase jumlah skor responden sebesar (74,34\%) yang artinya bahwa secara keseluruhan responden menjawab setuju. Hal ini mengindikasikan bahwa para pegawai memahami pentingnya disiplin yang dimiliki untuk mentaati kegiatan di perusahaan, walaupun masih ada yang menyatakan kurangnya kedisiplinan yang dimilikinya.

Tabel 6

Rekapitulasi Jawaban Responden Variabel Kompensasi

\begin{tabular}{|c|c|c|c|c|c|c|c|c|}
\hline \multirow{2}{*}{ No } & \multirow{2}{*}{$\begin{array}{c}\text { Pertanyaan } \\
\text { (Kompensasi) }\end{array}$} & & \multicolumn{5}{|c|}{ Skor Jawaban Responden } & \multirow{2}{*}{$\begin{array}{c}\text { Jumlah } \\
\text { Skor }\end{array}$} \\
\hline & & & 5 & 4 & 3 & 2 & $\mathbf{1}$ & \\
\hline \multirow[t]{2}{*}{1} & $\begin{array}{l}\text { Gaji sesuai standar } \\
\text { perusahaan }\end{array}$ & $\mathrm{f}$ & 14 & 23 & 2 & 5 & 1 & 179 \\
\hline & & $\%$ & 31,1 & 51,1 & 4,4 & 11,1 & 2,2 & 79,55 \\
\hline \multirow[t]{2}{*}{2} & $\begin{array}{c}\text { Gaji sesuai dengan } \\
\text { pekerjaan yang } \\
\text { dilakukan }\end{array}$ & $\mathrm{f}$ & 14 & 22 & 3 & 6 & 0 & 179 \\
\hline & & $\%$ & 31,1 & 48,9 & 6,7 & 13,3 & 0 & 79,55 \\
\hline \multirow[t]{2}{*}{3} & $\begin{array}{c}\text { Mendapatkan bonus } \\
\text { diluar gaji }\end{array}$ & f & 2 & 27 & 12 & 4 & 0 & 162 \\
\hline & & $\%$ & 4,4 & 60,0 & 26,7 & 8,9 & 0 & 72 \\
\hline \multirow[t]{2}{*}{4} & $\begin{array}{l}\text { Bonus yang diterima } \\
\text { sesuai pencapaian }\end{array}$ & $\mathrm{f}$ & 7 & 18 & 8 & 9 & 3 & 152 \\
\hline & & $\%$ & 15,6 & 40,0 & 17,8 & 20,0 & 6,7 & 67,55 \\
\hline
\end{tabular}




\begin{tabular}{|c|c|c|c|c|c|c|c|c|}
\hline 5 & $\begin{array}{c}\text { Bonus meningkatkan } \\
\text { semangat kerja }\end{array}$ & $\mathrm{f}$ & 10 & 19 & 7 & 7 & 2 & 163 \\
\hline \multirow{3}{*}{6} & \multirow{3}{*}{$\begin{array}{c}\text { Memberikan rasa aman } \\
\text { dan nyaman }\end{array}$} & $\%$ & 22,2 & 42,2 & 15,6 & 15,6 & 4,4 & 72,44 \\
\hline & & $\mathrm{f}$ & 9 & 18 & 13 & 5 & 0 & 166 \\
\hline & & $\%$ & 20,0 & 40,0 & 28.9 & 11,1 & 0 & 73,77 \\
\hline \multirow[t]{2}{*}{7} & \multirow{2}{*}{$\begin{array}{l}\text { Fasilitas sesuai } \\
\text { kebutuhan }\end{array}$} & $\mathrm{f}$ & 15 & 14 & 6 & 6 & 4 & 165 \\
\hline & & $\%$ & 33,3 & 31,1 & 13,3 & 13,3 & 8,9 & 73,33 \\
\hline \multirow[t]{2}{*}{8} & \multirow[t]{2}{*}{$\begin{array}{c}\text { Fasilitas menunjang } \\
\text { pekerjaan }\end{array}$} & $\mathrm{f}$ & 13 & 17 & 12 & 3 & 0 & 175 \\
\hline & & $\%$ & 28,9 & 37,8 & 26,7 & 6,7 & 0 & 77,77 \\
\hline \multirow[t]{4}{*}{9} & $\begin{array}{l}\text { Kepuasan terhadap } \\
\text { pekerjaan yang } \\
\text { dilakukan }\end{array}$ & $\mathrm{f}$ & 11 & 23 & 9 & 0 & 2 & 176 \\
\hline & & $\%$ & 24,4 & 51,1 & 20,0 & 0 & 4,4 & 78,22 \\
\hline & Total & $\mathrm{f}$ & 95 & 181 & 72 & 45 & 12 & 1517 \\
\hline & Total & $\%$ & 23,45 & 44,69 & 17,77 & 11,11 & 2,96 & 74,90 \\
\hline
\end{tabular}

Pada Tabel 6 dapat dilihat bahwa total frekuensi jawaban dan persentase jumlah skor responden tentang variabel kompensasi yang menyatakan sangat setuju terdapat 95 jawaban $(23,45 \%)$, setuju 181 jawaban $(44,69 \%)$, kurang setuju 72 jawaban $(17,77 \%)$, tidak setuju 45 jawaban $(11,11 \%)$ dan sangat tidak setuju 12 jawaban $(2,96 \%)$.

Kemudian secara keseluruhan persentase jumlah skor responden sebesar (74,90\%) yang artinya bahwa secara keseluruhan responden menjawab setuju. Hal ini mengindikasikan bahwa para pegawai memahami pentingnya kompensasi yang terima untuk bisa memotivasi dan mendukung para pegawai dalam bekerja di perusahaan, walaupun masih ada yang menyatakan kurangnya kompensasi yang diterima dan dikeluarkan perusahaan menurut pegawai belum pas dengan apa yang mereka kerjakan.

Tabel 7

Rekapitulasi Jawaban Responden Variabel Kinerja Pegawai

\begin{tabular}{|c|c|c|c|c|c|c|c|c|}
\hline \multirow{2}{*}{ No } & \multirow{2}{*}{$\begin{array}{c}\text { Pertanyaan (Kinerja } \\
\text { Pegawai) }\end{array}$} & & \multicolumn{5}{|c|}{ Skor Jawaban Responden } & \multirow{2}{*}{$\begin{array}{l}\text { Jumlah } \\
\text { Skor }\end{array}$} \\
\hline & & & 5 & 4 & 3 & 2 & 1 & \\
\hline \multirow[t]{2}{*}{1} & $\begin{array}{l}\text { Pekerjaan yang } \\
\text { dilakukan sesuai }\end{array}$ & $\mathrm{f}$ & 13 & 17 & 8 & 5 & 2 & 169 \\
\hline & & $\%$ & 28,9 & 37,8 & 17,8 & 11,1 & 4,4 & 75.11 \\
\hline \multirow[t]{2}{*}{2} & $\begin{array}{l}\text { Bekerja dari dalam hati } \\
\text { karena minat dan niat }\end{array}$ & f & 11 & 17 & 15 & 2 & 0 & 172 \\
\hline & & $\%$ & 24,4 & 37,8 & 33,3 & 4,4 & 0 & 76,44 \\
\hline \multirow[t]{2}{*}{3} & $\begin{array}{l}\text { Memberikan dorongan } \\
\text { mental yang besar bila }\end{array}$ & f & 8 & 24 & 12 & 0 & 1 & 173 \\
\hline & & $\%$ & 17,8 & 53,3 & 26,7 & 0 & 2,2 & 76,88 \\
\hline
\end{tabular}




\begin{tabular}{cccccccc}
\hline $4 \quad \begin{array}{c}\text { Timbal balik terhadap } \\
\text { perusahaan }\end{array}$ & $\mathrm{f}$ & 14 & 24 & 7 & 0 & 0 & 187 \\
& $\%$ & 31,1 & 53,3 & 15,6 & 0 & 0 & 83,11 \\
Total & $\mathrm{f}$ & 46 & 82 & 42 & 7 & 3 & 701 \\
& $\%$ & 25,55 & 45,55 & 23,33 & 3,88 & 1,66 & 77,88 \\
\hline
\end{tabular}

Pada Tabel 7 dapat dilihat bahwa total frekuensi jawaban dan persentase jumlah skor responden tentang variabel kinerja pegawai yang menyatakan sangat setuju terdapat 46 jawaban $(25,55 \%)$, setuju 82 jawaban $(45,55 \%)$, kurang setuju 42 jawaban $(23,33 \%)$, tidak setuju 7 jawaban $(3,88 \%)$ dan sangat tidak setuju 3 jawaban $(1,66 \%)$.

Kemudian secara keseluruhan persentase jumlah skor responden sebesar $(77,88 \%)$ yang artinya bahwa secara keseluruhan responden menjawab setuju. Hal ini mengindikasikan bahwa para pegawai memahami pentingnya kinerja pegawai yang baik untuk bisa mencapai tujuan perusahaan, walaupun masih ada yang menyatakan kurangnya kinerja pegawai yang diterapkan sehingga rasa taat dan dorongan untuk kerja tidak diperoleh dalam diri pegawai.

\section{Analisis data}

Pengujian instrumen penelitian

1) Uji reliabilitas

Uji reliabilitas adalah alat untuk mengukur suatu kuisioner yang merupakan indikator dari variabel. Suatu kuisioner dikatakan reliabel atau handal jika jawaban seseorang terhadap pernyataan tersebut konsisten atau stabil dari waktu ke waktu. Untuk mengukur reliabilitas digunakan uji statistik Cronbach Alpha $(\alpha)$. Pengujian ini dilakukan dengan melihat nilai Cronbach Alpha pada data yang diolah oleh program bantuan SPSS. Suatu variabel dikatakan reliabel jika memberikan nilai Cronbach Alpha $>0.60$. Sedangkan jika sebaliknya, data tersebut dikatakan tidak reliabel (Imam Ghozali, 2007,41-42). Berikut ini hasil perhitungan reliabilitas dengan menggunakan SPSS versi 23.0.

\section{Tabel 8}

Reliability Statistics

\begin{tabular}{|r|r|r|}
\hline $\begin{array}{c}\text { Cronbach's } \\
\text { Alpha }\end{array}$ & $\begin{array}{c}\text { Cronbach's } \\
\text { Alpha Based on } \\
\text { Standardized } \\
\text { Items }\end{array}$ & N of Items \\
\hline, 778 &, 792 & \multicolumn{1}{c|}{8} \\
\hline
\end{tabular}

Sumber: Output SPSS

Berdasarkan Tabel 8 menunjukkan Cronbach's Alpha $0.778 \geq 0.60$. Dapat disimpulkan bahwa pernyataan-pernyataan dalam variabel disiplin adalah reliable, artinya bahwa hasil pengukuran variabel disiplin adalah konsisten. 
Tabel 9

Reliability Statistics

\begin{tabular}{|c|c|c|}
\hline $\begin{array}{c}\text { Cronbach's } \\
\text { Alpha }\end{array}$ & $\begin{array}{c}\text { Cronbach's } \\
\text { Alpha Based on } \\
\text { Standardized } \\
\text { Items }\end{array}$ & $\mathrm{N}$ of Items \\
\hline ,808 & ,819 & 9 \\
\hline
\end{tabular}

Berdasarkan Tabel 9 menunjukkan Cronbach's Alpha $0.808 \geq 0.60$. Dapat disimpulkan bahwa pernyataan-pernyataan dalam variabel kompensasi adalah reliable, artinya bahwa hasil pengukuran variabel kompensasi adalah konsisten.

Tabel 10

Reliability Statistics

\begin{tabular}{|r|r|r|}
\hline $\begin{array}{c}\text { Cronbach's } \\
\text { Alpha }\end{array}$ & $\begin{array}{c}\text { Cronbach's } \\
\text { Alpha Based on } \\
\text { Standardized } \\
\text { Items }\end{array}$ & N of Items \\
\hline, 728 &, 735 & 4 \\
\hline
\end{tabular}

Sumber: Output SPSS

Berdasarkan Tabel 10 menunjukkan Cronbach's Alpha 0.728 $\geq 0.60$. Dapat disimpulkan bahwa pernyataan-pernyataan dalam variabel kinerja pegawai adalah reliable, artinya bahwa hasil pengukuran variabel kinerja pegawai adalah konsisten.

Ringkasan Uji Reliabilitas Variabel X dan Y

Tabel 11

Ringkasan Reliability Statistics

\begin{tabular}{l|l|l|l}
\hline No & \multicolumn{1}{|c|}{ Variabel } & \multicolumn{1}{|c}{$\begin{array}{c}\text { Cronbach's } \\
\text { Alpha }\end{array}$} & \multicolumn{1}{|c}{ Kesimpulan } \\
\hline 1 & Disiplin & .778 & Reliable \\
2 & Kompensasi & .808 & Reliable \\
3 & Kinerja Pegawai & .728 & Reliable \\
\hline
\end{tabular}

Sumber: Output SPSS

Berdasarkan Tabel 11 menunjukkan Cronbach's Alpha $\geq 0.60$. Dapat disimpulkan bahwa pernyataan-pernyataan dalam variabel disiplin, kompensasi dan kinerja pegawai adalah reliable, artinya bahwa hasil pengukuran variabelvariabel tersebut adalah konsisten.

2) Uji validitas

Menurut Imam Ghozali $(2007,45)$ uji validitas digunakan untuk mengukur sah atau valid tidaknya kuisioner. Suatu kuisioner dikatakan valid jika pertanyaan pada kuisioner mampu untuk mengungkapkan sesuatu yang akan diukur pada kuisioner tersebut. Teknik pengujian validitas dalam penelitian ini dilakukan dengan satu kali pengukuran dengan mengunakan metode Alpha. Sedangkan untuk menguji validitas dilakukan dengan menggunakan bantuan SPSS dengan terlebih dahulu 
menentukan nilai $r$ tabel berdasarkan nilai df (Degree of Freedom) serta tingkat signifikansi sebesar 5\%.

Setelah itu dicari nilai rhitung. Nilai rhitung sendiri diperoleh dari rumusan korelasi yang dihasilkan oleh SPSS pada kolom corrected item total correlation. Dan dasar pengambilan keputusannya adalah sebagi berikut :

a). Jika $r$ hitung $>r$ tabel $\alpha=5 \%$, maka butir pertanyaan dinyatakan valid

b). Jika $r$ hitung $<r$ tabel $\alpha=5 \%$, maka butir pertanyaan dinyatakan tidak valid

Uji validitas ini dilakukan dengan membandingkan nilai $r_{\text {hitung }}$ dengan $r_{\text {tabel }}$ untuk df $=n-k-1$. Dalam penelitian ini $\mathrm{df}=45-2-1$ atau $\mathrm{df}=42$ dengan $\alpha 0,05$ didapat $r_{\text {tabel }}$ sebesar 0,297. Jika $r_{\text {hitung }}$ (per item) lebih besar dari $r_{\text {tabel }}$ berarti pernyataan tersebut dikatakan valid. Hasil uji validitas untuk $r_{\text {hitung }}$ (per item) dapat dilihat dalam hasil output SPSS pada pada kolom Corrected Item-Total Correlation seperti yang disajikan sebagai berikut :

Tabel 12

Validity Statistics

\begin{tabular}{|c|c|c|c|}
\hline & $\begin{array}{c}\text { Corrected } \\
\text { Item-Total } \\
\text { Correlation }\end{array}$ & r-tabel & Keterangan \\
\hline p1 & .794 & 0.297 & Valid \\
\hline p2 & .722 & 0.297 & Valid \\
\hline p3 & .554 & 0.297 & Valid \\
p4 & .507 & 0.297 & Valid \\
p5 & .337 & 0.297 & Valid \\
p6 & .749 & 0.297 & Valid \\
p7 & .652 & 0.297 & Valid \\
p8 & .781 & 0.297 & Valid \\
\hline
\end{tabular}

Sumber: Output SPSS

Berdasarkan tabel 12 pada kolom Correctedd Item Total Statistic $\left(\mathrm{r}_{\text {hitung }}\right.$ ) untuk masing-masing item atau butir pernyataan nilainya lebih besar dari $r_{\text {tabel }}$ 0.297 , sehingga dapat disimpukan bahwa 8 pernyataan untuk variabel disiplin adalah valid.

Tabel 13

Validity Statistics

\begin{tabular}{c|c|c|c}
\hline & $\begin{array}{c}\text { Corrected } \\
\text { Item-Total } \\
\text { Correlation }\end{array}$ & r-tabel & Keterangan \\
\hline $\mathrm{p}_{1}$ & .699 & 0.297 & Valid \\
$\mathrm{p}_{2}$ & .785 & 0.297 & Valid \\
$\mathrm{p}_{3}$ & .709 & 0.297 & Valid \\
$\mathrm{p}_{4}$ & .536 & 0.297 & Valid \\
$\mathrm{p}_{5}$ & .482 & 0.297 & Valid \\
$\mathrm{p}_{6}$ & & 0.297 & Valid \\
\hline
\end{tabular}




\begin{tabular}{l|l|l|l}
\hline $\mathrm{p}_{7}$ & .327 & 0.297 & Valid \\
$\mathrm{p}_{8}$ & .762 & 0.297 & Valid \\
$\mathrm{p}_{9}$ & .659 & 0.297 & Valid \\
& .782 & & \\
\hline
\end{tabular}

Sumber: Output SPSS

Berdasarkan tabel 13 pada kolom Correctedd Item Total Statistic ( $\mathrm{r}_{\text {hitung }}$ ) untuk masing-masing item atau butir pernyataan nilainya lebih besar dari $r_{\text {tabel }}$ 0.297, sehingga dapat disimpukan bahwa 9 pernyataan untuk variabel kompensasi adalah valid.

Tabel 14

Validity Statistics

\begin{tabular}{cccc}
\hline & $\begin{array}{c}\text { Corrected Item-Total } \\
\text { Correlation }\end{array}$ & r-tabel & Keterangan \\
\hline $\mathbf{P}_{\mathbf{1}}$ & .855 & 0.297 & Valid \\
$\mathbf{P}_{\mathbf{2}}$ & .784 & 0.297 & Valid \\
$\mathbf{P}_{\mathbf{3}}$ & .622 & 0.297 & Valid \\
$\mathbf{P}_{\mathbf{4}}$ & .710 & 0.297 & Valid \\
\hline \multicolumn{4}{c}{}
\end{tabular}

Berdasarkan tabel 14 pada kolom Correctedd Item Total Statistic ( $\mathrm{r}_{\text {hitung }}$ ) untuk masing-masing item atau butir pernyataan nilainya lebih besar dari $\mathrm{r}_{\text {tabel }}$ 0.297, sehingga dapat disimpukan bahwa 4 pernyataan untuk variabel kinerja pegawai adalah valid.

\section{E. SIMPULAN}

\section{Disiplin (X1) berpengaruh secara signifikan terhadap Kinerja Pegawai (Y)}

Penelitian ini menunjukan bahwa disiplin memiliki pengaruh yang signifikan terhadap kinerja pegawai. Artinya, dalam bekerja pegawai perlu memahami aturan untuk mengatur diri sendiri dan lingkungan kerja, timbulnya rasa patuh (bersedia) pada diri sendiri, dapat mengendalikan emosi, dapat memotivasi diri, memahami perasaan orang lain, bekerjasama dan berkomunikasi dengan baik pada orang lain atau rekanan kerja.

Kinerja merupakan hasil kerja yang dicapai oleh pegawai dalam melaksanakan tugasnya sesuai dengan tanggung jawab yang diberikan padanya, dan menjadi salah satu tolak ukur yang digunakan untuk menentukan apakah suatu pekerjaan yang dilakukan akan baik atau sebaliknya. Kinerja menjadi perhatian utama, baik bagi klien ataupun publik, dalam menilai hasil kerja yang dilakukan. Jika seorang pegawai tidak memiliki sikap disiplin yang baik maka kinerjanya akan terganggu karena dapat menimbulkan rasa tidak nyaman dalam bekerja dan bisa menurunkan kinerja karena mempunyai dampak negative terhadap diri sendiri dan orang lain, seperti timbulnya kesalah pahaman, salahnya komunikasi, penurunan kerjasama yang baik sehingga bisa menurunkan kinerja pegawai secara keseluruhan. 
Hasil penelitian ini konsisten dengan penelitian sebelumnya yang dilakukan oleh M. Harlie pada tahun 2010. Penelitian yang dilakukan M. Harlie menunjukan Disiplin berpengaruh secara signifikan terhadap kinerja pegawai. Kesimpulan ini dibuktikan dengan melihat nilai sig yaitu sebesar $0.001<0.05$

\section{Kompensasi (X2) berpengaruh secara signifikan terhadap Kinerja Pegawai (Y)}

Penelitian ini menunjukan bahwa kompensasi memiliki pengaruh yang signifikan terhadap kinerja pegawai. Artinya, saat diberikan tugas karyawan merasa senang dengan pekerjaan yang diberikan. Ada kondisi yang mempengeruhi pegawai dalam hal membangkitkan, mengarahkan dan memelihara perilaku yang berhubungan dalam lingkungan kerja serta adanya daya pendorong yang menentukan prestasi kerja yang berhubungan dengan lingkungan kerja.

Kinerja merupakan hasil kerja yang dicapai oleh pegawai dalam melaksanakan tugasnya sesuai dengan tanggung jawab yang diberikan padanya, dan menjadi salah satu tolak ukur yang digunakan untuk menentukan apakah suatu pekerjaan yang dilakukan akan baik atau sebaliknya. Kinerja menjadi perhatian utama, baik bagi rekan kerja ataupun perusahaan, dalam menilai hasil kerja yang dilakukan. Jika seorang pegawai mempunyai kompensasi yang sesuai dengan apa yang dikerjakannya maka motivasi dalam bekerja akan meningkat sehingga kinerjanya akan meningkat sedemikian rupa.

Meningkatkan kinerja pegawai mempunyai dampak positif terhadap perilaku individu, seperti timbulnya loyalitas kerja, meningkatkan kepuasan kerja, menurunkan stress kerja serta meningkatkan produktifitas kerja sehingga bisa meningkatkan kinerja pegawai secara keseluruhan.

Hasil penelitian ini konsisten dengan penelitian sebelumnya yang dilakukan oleh Yuli Suwati pada tahun 2013. Penelitian yang dilakukan Yuli Suwati menunjukan bahwa kompensasi berpengaruh secara signifikan terhadap kinerja pegawai. Kesimpulan ini dibuktikan dengan melihat nilai sig yaitu sebesar $0.005<0.05$

\section{Disiplin (X1), Kompensasi (X2) cukup berpengaruh secara signifikan terhadap Kinerja Pegawai (Y)}

Hasil penelitian ini menunjukan bahwa Disiplin dan Kompensasi secara bersamasama cukup memiliki pengaruh yang signifikan terhadap Kinerja Pegawai sebesar 0,675 dengan tingkat signifikan sebesar $0.000<0.05$. Artinya, Disiplin dan Kompensasi secara bersama-sama memiliki pengaruh yang signifikan sebesar $67.50 \%$ terhadap Kinerja Pegawai, sedangkan sisanya sebesar $32.50 \%$ dipengaruhi oleh faktor-faktor lain diluar model penelitian, antara lain stress kerja, gaya kepemimpinan, kepuasan kerja, komitmen organisasi dan lain sebagainya juga turut mempengaruhi kinerja pegawai, dan dapat digunakan sebagai refensi bagi penelitian selanjutnya.

Dalam rangka meningkatkan kinerja pegawai, pengawasan dalam rangka peningkatan disiplin dapat membantu pegawai dalam melaksanakan tugasnya agar menjadi lebih baik, sehingga dapat meningkatkan kinerja pegawai. Dengan demikian pegawai yang memiliki sikap kedisiplinan kurang baik akan terminimalisasi pelanggarannya kemudian dari masalah kompensasi akan terselesaikan karena apabila pegawai itu disiplin contoh seperti tepat waktu 
kekantor, tepat waktu menyelesaikan tugas dan tidak melanggar aturan maka kompensasi yang diterima pegawai akan sesuai dengan apa yang dikerjakannya selama sebulan tanpa harus menerima potongan karna tidak disiplin dalam lingkungan pekerjaan dan perusahaan.

\section{DAFTAR PUSTAKA}

Arikunto, Suharsimi. Prosedur Penelitian Suatu Pendekatan Praktik, PT. Rineka Cipta, Jakarta. 2013.

Eko Widodo, Suparno. Manajemen Pengembangan Sumber Daya Manusia, Pustaka Pelajar, Yogyakarta. 2015.

Ghozali, Imam. Aplikasi Analisis Multivariate dengan Program SPSS edisi 3, BP UNDIP, Semarang. 2007.

Hadari, Nawawi. Metodelogi Penelitian Bidang Sosial, Gajah Mada University Press, Yogyakarta. 2007.

Hasibuan, Malayu SP. Manajemen Sumber Daya Manusia, Bumi Aksara, Jakarta. 2009.

Handoko T. Hani. Manajemen Personalia dan Sumber Daya Manusia, BPFE, Yogyakarta. 2008.

Harlie, Muhammad. Pengaruh Disiplin Kerja, Motivasi dan Pengembangan Karir terhadap Kinerja Pegawai Negeri Sipil Pada Pemerintah Kabupaten Tabalongn di Tanjung Kalimantan Selatan. 2010.

Indrianto, dkk. Metodelogi Penelitian Bisnis Untuk Akuntansi \& Manajemen, BPFE, Yogyakarta. 2007.

Mangkunegara, Anwar Prabu. Evaluasi Kinerja SDM, PT Refika Aditama, Bandung. 2010.

Perencanaan dan Pengembangan Sumber Daya Manusia, PT Refika Aditama, Bandung. 2011.

Manajemen Sumber Daya Manusia Perusahaan, PT. Remaja Rosdakarya, Bandung. 2013.

Notoatmodjo, Soekidjo. Pengembangan Sumber Daya Manusia, Edisi Revisi, Cetakan Ketiga, PT. Rineka Cipta, Jakarta. 2007. 
Rivai, Veithzal. Manajemen Sumber Daya Manusia untuk Perusahaan, Raja Grafindo Persada, Jakarta. 2007.

Supardi. Aplikasi Statistika dalam Penelitian, PT. Ufuk Publishing House, Jakarta. 2012.

Suryabrata, Sumadi. Metodologi Penelitian, Rajawali Pers, Jakarta. 2015.

Sutrisno, Edy. Manajemen Sumber Daya Manusia, Prenadamedia Group, Jakarta. 2009.

Yani, M. Manajemen Sumber Daya Manusia, Mitra Wacana Media, Jakarta. 2012.

Wibowo. Manajemen Kinerja, PT. Raja Grafindo Persada, Jakarta. 2007. 